\title{
Review
}

\section{Review of some features of the biology of Strongyloides westeri with emphasis on the life cycle}

\author{
E.T. LYONS*, S.C. TOLLIVER
}

Department of Veterinary Science, University of Kentucky, Gluck Equine Research Center, Lexington, Kentucky 40546-0099,

*E-mail: elyons1@uky.edu

\section{Article info}

Received August 24, 2014 Accepted October 15, 2014

\begin{abstract}
Summary
Review of several aspects of the biology of Strongyloides westeri, especially on the life cycle, are presented. The main reason is because of the potential renewed importance of these parasites since the recently recognized increase in their prevalence in horse foals. Indications are that the first and main source of enteric infections in foals maturing to adults in their small intestines is from parasitic third stage larvae $\left(L_{3}\right)$ passing to them in milk of their dams. It appears that a lesser source of infection is from free-living $L_{3}$ which, when they are ingested with food or penetrate the skin, can mature in foals. In conclusion, the source of enteric infections of adult $S$. westeri in foals is mainly from parasitic $\mathrm{L}_{3}$ that they ingest in milk of their dams.
\end{abstract}

Keywords: review; life cycle; Strongyloides westeri; equids

\section{Introduction}

Strongyloides westeri Ihle, 1917, an internal parasite of equids, was highly prevalent (about $90 \%$ ) in foals in the Central Kentucky and other geographical areas over 40 years ago (Todd et al., 1949). Then for a period of time (by the late 1990s and early 2000s) the prevalence declined tremendously because of the use of highly effective compounds like thiabendazole and ivermectin. However, a recent publication demonstrated that the prevalence has increased several fold, probably due to less use of ivermectin in foals, because of drug resistance of another nematode, the ascarid (Parascaris equorum), in young equids (Lyons \& Tolliver, 2014). The possible role of $S$. westeri as a cause of diarrhea in foals is equivocal but cannot be overlooked. Review of some aspects of the biology of S.westeri is presented here to highlight a few characteristics of these parasites, mainly because of renewed interest in them since the recent finding of their increased prevalence. Presentation of the life cycle of $S$. westeri combining narrative and drawing is believed by the authors to be more detailed than in previous publications. The drawing provides the essence of the life cycle because of the detailed visual depiction of it.

\section{General aspects of the genus Strongyloides}

The nematode genus Strongyloides contains over 50 species; this is an unusually high number for a single genus (Speare,
1989). Also unusual is the varied category of hosts which include several species of amphibians, birds, mammals, and reptiles (Speare, 1989). Infections are usually located in the mucosa of the anterior end of the small intestine (Speare, 1989). Parasitic adults are all females and reproduction is by parthenogenesis i.e. fertile eggs are produced by the females without insemination. Thus parasitic males are not needed and are not present in the host. Further information on reproduction of Strongyloides is presented on the life cycle of $S$. westeri later in this paper.

\section{Clinical features of Strongyloides westeri}

The intestinal threadworm, $S$. westeri, can be found as an adult in the small intestines of young foals (Drudge \& Lyons, 1989). It is the first nematode that matures in foals and embryonated eggs appear in their feces at about two weeks of age. These parasites apparently induce an immune response resulting in self-care typically when foals are about six months old. Thus adult infections are not found in horses older than weanlings and yearlings. Detrimental effects of intestinal infections of these parasites in foals are difficult to prove. They have been incriminated as a cause of diarrhea in foals. Usually the typical first diarrhea in foals is the so-called nine-day scour condition associated with the foaling heat period in mares but is not caused by $S$. westeri. This situation is self-limiting. Usually the only effect is denuding of hair in the perianal area due to irritation caused by the wet liquid 


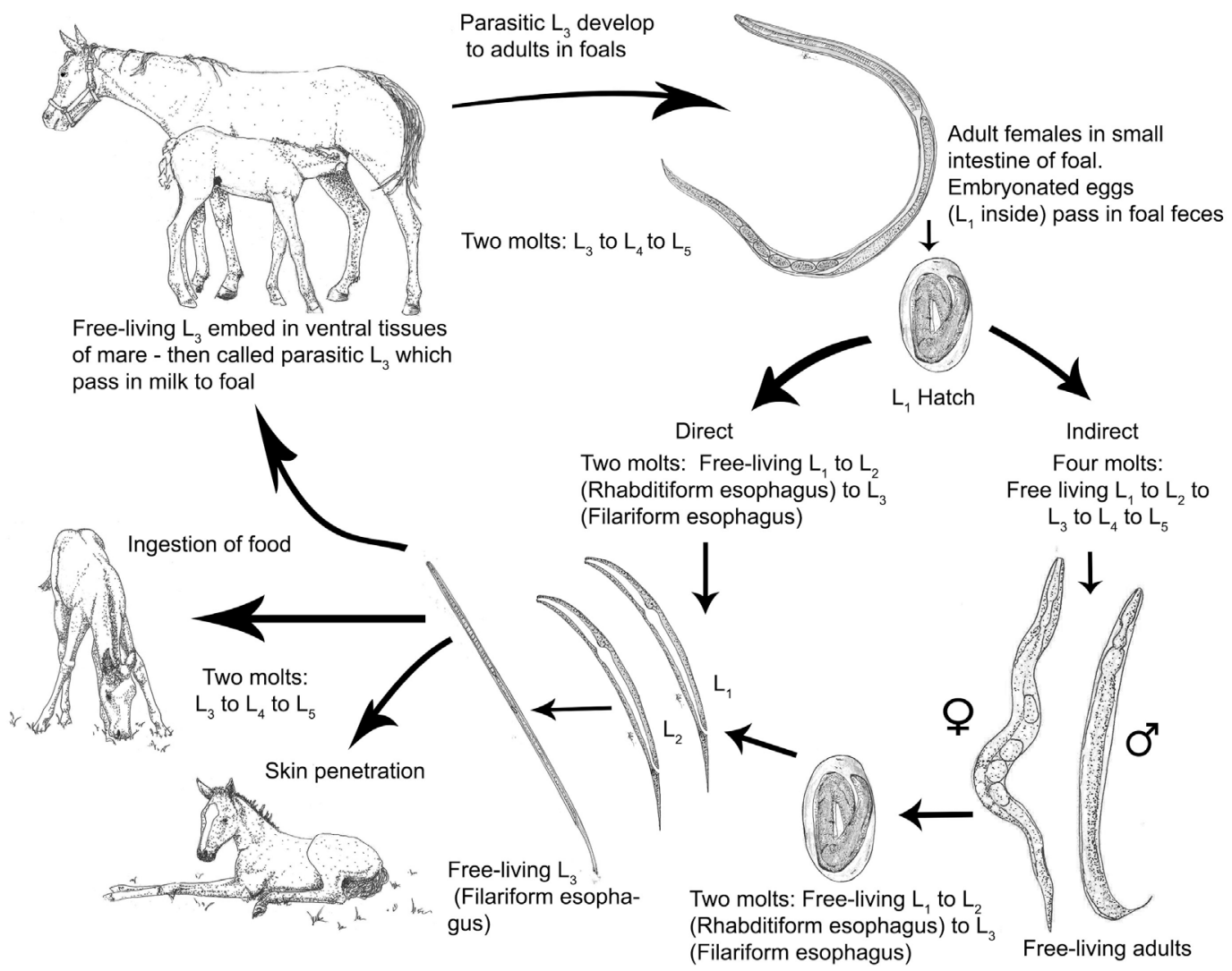

Fig. 1. Life cycle of Strongyloides westeri indicating that adults in the small intestine of foals develop from three sources: parasitic $L_{3}$ ingested in milk of the dam and from free-living $L_{3}$ swallowed with food or penetrating the skin

feces. Later diarrheas may be related to $S$. westeri. However, egg counts are not necessarily indicative that these parasites are the cause because there may be high counts of eggs per gram of feces (EPGs) without diarrhea but low EPGs and diarrhea. Some equine practitioners, when causes of diarrheas in foals are not readily diagnosed, treat them with drugs like ivermectin or oxibendazole which are efficacious on $S$. westeri. If diarrheas then cease, there is an impression that killing of these parasites maybe indicated they indeed were the cause of the problem. Filariform larvae $\left(\mathrm{L}_{3}\right)$ may cause dermatitis when penetrating the skin of horses (Dewes \& Townsend, 1990). These authors base this opinion as the cause of extreme discomfort and hyperactivity of two horses, apparently after laying on the ground, because in this area, finding $S$. westeri infective $\mathrm{L}_{3}$ in the soil with low $\mathrm{pH}$ and sawdust; in addition there were warm moist conditions which helped protect the larvae from dessication. Parasiticides approved in the USA for activity on luminal infections of $S$. westeri include ivermectin and oxibendazole. There was some reduction of transmission of $S$. westerii larvae through milk of mares after their treatment with injectable ivermection; conclusions were based on lower eggs counts in foals suckling these ivermectintreated mares compared to foals suckling non-ivermection treated mares. (Ludwig et al., 1983). Also there was indication that multi-day cambendazole treatment of mares reduced or blocked transmammary transmission of larvae to their suckling foals as long as the mares were being treated.(Lyons et al., 1977).Studies have shown high efficacy of predatory fungi on free-living S. westeri L3 (Araujo et. al., 2010; 2012).

\section{Review of Life cycle of Strongyloides westeri}

A review of the life cycle of $S$. westeri is presented (Fig 1). Strongyloides westeri is similar to Strongyloides papillosus Wedl, 1856; Ransom, 1911 in having two" types" of life cycles (Fig.1) according to Olsen (1974):

1) Homogonic (direct): Parthenogenic adult females, which reside in the small intestines of young equids, lay eggs which are embryonated when they pass in the host feces into the environment and develop into free-living stages. From these eggs, $L_{1}$ larvae hatch and molt into $L_{2}$; both of these stages have a rhabditiform esophagus which has an anterior thick region and a posterior bulb. The $L_{2}$ then molt to the free-living $(F L) L_{3}$; they have a filariform esophagus which is long and without a posterior bulb. The $F L L_{3}$ enter equids via the mouth or skin. If swallowed, $F L L_{3}$ molt twice to become adult females in the small intestine. FL $L_{3}$ entering skin go into blood vessels and through the heart to the lungs, molt once, enter the trachea and pharynx, are swallowed, and molt again to adult females in the small intestine.

2) Heterogonic (indirect): Eggs pass in feces of hosts in the environment and develop through four stages into rhabditiform adult males and females. These females lay eggs which go through the same three stages $\left(L_{1}, L_{2}\right.$ and $\left.L_{3}\right)$ in the environment like occurs with eggs from homogonic females; the $F L L_{3}$ enter the mouth with food or penetrate the skin and molt twice to become adult parthenogenic females in the small intestines. Viney \& Lok (2007) mention that most species of Strongyloides have only one free-living adult generation. Thus it is assumed that is 
the situation with $S$. westeri although apparently this has not been verified.

Transmammary transmission of $S$. westeri is believed to be the main manner of infection of the equid foal (Lyons et al., 1973). Parasitic $L_{3}$ have been recovered from milk of mares for 4 to 47 days postpartum. Periodicity of the shedding of parasitic $L_{3}$ in the milk of mares was observed. In 24-hour studies, over two thirds of the larvae were passed in the milk in the AM vs. about onethird in the PM. Parasitic $L_{3}$ from milk of mares, given to wormfree foals, matured in them. Thus this demonstrated the capability of this source of larvae maturing in foals. Likewise it was shown experimentally that adult $S$. westeri developed in worm-free foals from exposure of $F L L_{3}$ via mouth or skin. Morphologically $F L L_{3}$ are slightly less developed than parasitic $L_{3}$. In experimental infections of worm-free foals, the prepatent period of 8 to 12 days when parasitic $L_{3}$ were given was overall shorter than that of 10 to 14 days when $F L L_{3}$ were administered. Some of the $F L L_{3}$ entering equids locate in tissues, especially in the ventral abdominal area. Parasitic L3 located there are at a "dead end" except for foaling mares in whose milk they pass to their suckling foals. No clinical indications of diarrhea caused by $S$. westeri were observed in any of these studies. In summary, three larval sources can develop into adults in foals: parasitic $L_{3}$ in the mother's milk and $F L L_{3}$ ingested with food or entering through the skin. No evidence of prenatal infection of $S$. westeri was detected in extensive research.

\section{Acknowledgments}

This investigation (paper No.14-14-059) is published with the approval of the Director of the University of Kentucky Agricultural Experiment Station. Special recognition is given to Heather BairBrake who designed and drew the life cycle of Strongyloides westeri.

\section{References}

ARaujo, J.M., ARaúJo, J.V., Braga, F.R., CARVAlho, R.O. (2010): In vitro predatory activity of nematophagous fungi and after passing through gastrointestinal tract of equine on infective larvae of Strongyloides westeri. Parasitol. Res., 107: 103 - 108. DOI: 10.1007/s00436-010-1841-y
Araujo, J.M, Araújo, J.V., Braga, F.R., Tavela, Ade O, Ferreira, S.R., SOARES, F.E., CARVALHO, G.R. (2012): Control of Strongyloides westeri by nematophagous fungi after passage through the gastrointestinal tract of donkeys. Rev. Bras. Parasitol. Vet., 21: 157 - 160. DOI: 10.1590/S1984-29612012000200016

DEWES, H.F., TOWNSEND, K.G. (1990): Further observations on Strongyloides westeri dermatitis: recovery of larvae from soil and bedding, and survival in treated sites. New Zeal. Vet. J., 38: 34 37. DOI: $10.1080 / 00480169.1990 .35612$

DRUDGE, J.H., LYONS, E.T. (1989): Internal parasites of equids with emphasis on treatment and control. Hoechst-Roussel (Monograph); revision of 1986 issue. $26 \mathrm{pp}$.

LUDWIG, K.G., CRAIG, T.M., BOWEN, J.M., ANSARI, M.M., LEY, W.B. (1983): Efficacy of ivermectin in controlling Strongyloides westeri infections in foals. Am. J. Vet. Res.44:314-316

LYONS, E.T., DRUDGE, J.H., TOLLIVER, S.C. (1973): On the life cycle of Strongyloides westeri in the equine. J. Parasitol., 59: 780 - 787. DOI: 10.1007/s00436-003-1068-2

LYONS, E.T., DRUDGE, J.H., TOLLIVER, S.C. (1977): Observations on development of Strongyloides westeri in foals nursing dams treated with cambendazole or thiabendazole. Am. J. Vet. Res. 38: $889-892$

LYONS, E.T., TOLLIVER, S.C. (2014): Prevalence of patent Strongyloides westeri infections in Thoroughbred foals in 2014. Parasitol. Res., Published On Line, August 23, 2014. DOI: 10.1007/ s00436-014-4088-1

MIRCK, M.H. (1977): Strongyloides westeri Ihle, 1917 (Nematoda: Strongyloididae). I. Parasitological features of natural infection. Tijdschr. Diergeneeskd., 102: 1039 - 1043 (In Dutch)

OLSEN, O.W. (1974): Animal Parasites - Their Life Cycles and Ecology. University Park Press, Baltimore. $56 \mathrm{pp}$.

SPEARE, R. (1989). Identification of species of Strongyloides. In: GROVE, D.I. (Ed) Strongyloidiasis: a Major Roundworm Infection. Taylor and Francis, London. pp 11 - 83.

Todd, A. C., Kelley, G. W., Wyant, Z. N., Hansen, M.F., Hull, F. E. (1949): Worm parasites in Thoroughbred sucklings and weanlings. A survey of incidence, development and control. Kentucky Agriculture Experiment Station Bulletin, 541, 24 pp.

VINEY, M.E., LOK, J.B. (2007): Strongyloides spp, WormBook In: J. Hodgkin, P. Anderson (Ed) The C. elegans Research Community, WormBook, DOI: 10.1895/wormbook.1.141.1 